\title{
Effects of litter inputs on soil respiration: a meta-analysis
}

\author{
Y.J. Zhang ${ }^{1}$, Zou Junliang ${ }^{2}$, Xue Siwen ${ }^{1}$, Dang Shuina ${ }^{1}$, Bruce Osborne ${ }^{3}$, Ren Yuanyuan ${ }^{1}$, \\ Liang Ting ${ }^{1}$, and Yu Keke ${ }^{1}$ \\ ${ }^{1}$ Baoji University of Arts and Sciences \\ ${ }^{2}$ Beijing Academy of Agricultural and Forestry Sciences \\ ${ }^{3}$ University College Dublin
}

April 28, 2020

\begin{abstract}
Whilst soil respiration is often increased in response to litter inputs, the magnitude of the effect and the underlying drivers remains poorly understood. We synthesized 66 recently published papers on forest ecosystems with 2436 observations using a meta-analysis approach to investigate the effect of litter inputs on soil respiration. The results showed that litter inputs had strong positive impacts on soil respiration, labile $\mathrm{C}$ availability, and the abundance of soil microorganisms, with less of an effect on soil moisture and temperature. The increase in soil respiration in response to litter inputs showed the following patterns: with coniferous forests $(50.7 \%)>$ broad-leaved forests $(41.3 \%)>$ mixed forests $(31.9 \%)$. The effect also depended on stand age with middle-aged forests $(53.3 \%)>$ mature forests $(50.2 \%)>$ young forests $(34.5 \%)$. Correspondingly, microbial biomass carbon (MBC) and dissolved organic carbon (DOC) were increased by $21.0 \%-33.6 \%$ and $60.3 \%-87.7 \%$, respectively, in response to normal and doubled litter inputs, whilst soil respiration increased linearly with increases in DOC and MBC. Normal and doubled litter inputs increased total PLFA (Phospholipid Fatty Acid) by $6.6 \%$ and 19.7\%, respectively, but decreased the fungal/bacterial PLFA ratio by $26.9 \%$ and $18.7 \%$, respectively. Increases in soil respiration in response to litter inputs were closely related with total PLFA, fungal PLFA, bacterial PLFA, and fungal/bacterial PLFA ratio. Therefore, in addition to forest type and stand age, labile $\mathrm{C}$ availability, and soil microorganisms are also important factors that influence soil respiration in response to litter inputs.
\end{abstract}

\section{Effects of litter inputs on soil respiration: a meta-analysis}

Zhang Yanjun $^{1}$, Zou Junliang ${ }^{2}$, Xue Siwen ${ }^{1}$, Dang Shuina ${ }^{3}$, Osborne Bruce ${ }^{4}$, Ren Yuanyuan ${ }^{1}$, Liang Ting ${ }^{1}$, Yu Keke ${ }^{1}$

1. Geography and Environmental Engineering Department, Baoji University of Arts and Sciences, Baoji 721013, China

2. Beijing Research 83 Development Centre for Grass and Environment, Beijing Academy of Agriculture and Forestry Sciences, Beijing 100097, China

3. School of Education, Baoji University of Arts and Sciences, Baoji 721013, China

4. UCD School of Biology and Environmental Science and UCD Earth Institute, University College Dublin, Belfield, Dublin 4, Ireland

(*Corresponding author: email: jlzou@nwafu.edu.cn, Tel.: 86-010-51503418)

I would like to declare on behalf of my co-authors that no conflict of interest exits in the submission of this manuscript, and manuscript is approved by all authors for publication. 
Abstract: Whilst soil respiration is often increased in response to litter inputs, the magnitude of the effect and the underlying drivers and their interrelationships remains poorly understood. We synthesized 66 recently published papers on forest ecosystems with 2436 observations using a meta-analysis approach to investigate the effect of litter inputs on soil respiration. The results showed that litter inputs had strong positive impacts on soil respiration, labile $\mathrm{C}$ availability, and the abundance of soil microorganisms, with less of an effect on soil moisture and temperature. Soil respiration was increased overall by $35.7 \%$ and $55 \%$, respectively, in response to normal and doubled litter inputs. The increase in soil respiration in response to litter inputs showed the following patterns: with coniferous forests $(50.7 \%)>$ broad-leaved forests $(41.3 \%)$ $>$ mixed forests $(31.9 \%)$. The effect also depended on stand age with middle-aged forests $(53.3 \%)>$ mature forests $(50.2 \%)>$ young forests $(34.5 \%)$. Correspondingly, microbial biomass carbon (MBC) and dissolved organic carbon (DOC) were increased by $21.0 \%-33.6 \%$ and $60.3 \%-87.7 \%$, respectively, in response to normal and doubled litter inputs, whilst soil respiration increased linearly with increases in DOC and MBC. Normal and doubled litter inputs increased total PLFA (Phospholipid Fatty Acid) by $6.6 \%$ and $19.7 \%$, respectively, but decreased the fungal/bacterial PLFA ratio by $26.9 \%$ and $18.7 \%$, respectively. Bacterial PLFA and fungal PLFA were decreased by $10.8 \%$ and $35.6 \%$ in response to normal litter inputs but increased by $29.8 \%$ and $10.8 \%$ in response to doubled litter inputs. Increases in soil respiration in response to litter inputs were closely related with total PLFA, fungal PLFA, bacterial PLFA, and fungal/bacterial PLFA ratio. Therefore, in addition to forest type and stand age, labile $\mathrm{C}$ availability, and soil microorganisms are also important factors that influence soil respiration in response to litter inputs.

Key Words: litter inputs; soil respiration; meta-analysis; soil microorganisms; labile C availability

Soils release approximately $98 \mathrm{Pg} \mathrm{C}$ to the atmosphere through soil respiration each year (Ben and Allison, 2010), which is ten times the rate of carbon emission by fossil fuel combustion (IPCC,2007). Rates of soil respiration have been increasing by approximately $0.1 \mathrm{Pg} \mathrm{C} \mathrm{yr}^{-1}$ since 1989 in response to global temperature increases (Ben and Allison, 2010), and small changes in soil respiration associated with climate change have the potential to influence atmospheric $\mathrm{CO}_{2}$ concentrations due to the large amounts of $\mathrm{C}$ stored in global soils (Ben and Allison, 2010). Although extensive work has reported that soil respiration could be greatly affected by abiotic and biotic factors, such as soil temperature and moisture, soil microorganisms and substrate supply (Wu et al., 2017; Tian et al., 2019), uncertainty remains about how substrate supply (e.g., litter inputs) and others factors (e.g., the microbial community and soil microclimate) interactively affect soil respiration under field conditions.

The impact of litter inputs on soil respiration can also vary with other factors, such as vegetation type (Han et al., 2015; Duan et al., 2018), successional stage (Han et al., 2015), stand age (Xin et al., 2016), experimental period (Sayer, 2006; Crow et al., 2009; Wang et al., 2009; Wang et al., 2013), climatic conditions (Sulzman et al., 2005; Deng et al., 2007; Zimmermann et al., 2009; Liang et al., 2010; Zhang et al., 2016), the quantity and quality of litter (Deng et al., 2007; Bréchet et al., 2018; Duan et al., 2018), topographic conditions (Duan et al., 2018; Zhang et al., 2020), soil temperature and moisture (Sulzman et al., 2005; Fekete et al., 2014), and soil physicochemical properties (e.g., soil pH, soil C:N, soil bulk density) (Pinto et al., 2018; Zhang et al., 2020). In addition, the response of soil respiration to litter inputs can also be influenced by soil microorganisms (e.g., microbial quantity and community structure) (Han et al., 2015; Leitner et al., 2016; Wu et al., 2017). For example, in a coniferous forest ecosystem, soil respiration, total PLFA, fungal PLFA, bacterial PLFA, and fungal/bacterial PLFA ratio were influenced significantly by litter inputs, and the increase of soil respiration was closely related with both the total PLFA and the fungal/bacterial PLFA ratio (Wu et al., 2017). However, it is still unclear which of these factors has the greater control over soil respiration in response to litter inputs.

The reported effects of litter inputs on soil microorganisms (e.g., microbial quantity and community structure) and soil respiration are also inconsistent. Although most studies have found that soil respiration was significantly increased by litter inputs (Kim et al., 2005; Sulzman et al., 2005; Sayer et al., 2007; Zimmermann et al., 2009; Zhang et al., 2016; Bréchet et al., 2018; Pinto et al., 2018; Zhang et al., 2020), a few studies have reported that soil respiration was not increased by litter inputs (Sun et al., 2005; Fekete et al., 2014). 
Furthermore, soil microbial biomass, has been found to increase (Wu et al., 2017), decrease (Wang et al., 2013; Leitner et al., 2016), or remain unchanged in response to litter inputs (Leitner et al., 2016). Similarly, bacterial/fungal PLFA ratio decreased (Wu et al., 2017) or increased (Wang et al., 2013) in response to litter inputs. Our current understanding of the interrelationships among litter inputs, soil microorganisms, and soil respiration are also extremely limited.

The Detritus Input and Removal Treatment (DIRT) experiment provides a unique opportunity to examine feedbacks between litter inputs, soil microorganisms, and soil respiration through long-term manipulation of aboveground litter inputs in forest ecosystems (Sulzman et al., 2005; Veres et al., 2015; Wu et al., 2017; Zhang Yanjun, 2017; Bréchet et al., 2018). As far as we know, there are some general articles about the effect of litter inputs on soil physicochemical and biological processes (Xu et al., 2013) and the effect of litter inputs on soil respiration (Lv and Wang, 2017; Zhang et al., 2020). Whilst there is also information from individual field experiments on the relationships among litter inputs, soil microorganisms and soil respiration (Leff et al., 2012; Wang et al., 2013; Han et al., 2015; Leitner et al., 2016; Wu et al., 2017), the results are very variable and the generality of the findings are unclear as they lack regional representation. Therefore, the primary objectives of this study were: (1) to examine how soil respiration and soil microorganisms respond to changes in litter inputs; (2) to quantify the relationship between soil respiration and soil microorganisms in response to litter inputs. To achieve these goals, we conducted a meta-analysis of 66 recent forest studies consisting of 2436 observations in which changes in soil respiration were investigated in response to different litter inputs treatments.

\section{Methods}

\subsection{Data selection}

Data were extracted from peer-reviewed publications that reported on soil respiration in both treatment plots (receiving litter inputs) and control plots (no-litter inputs). The relevant publications were selected via searching keywords using the terms "litter respiration", "contribution of litter respiration to soil respiration", "effect of litter on soil respiration", and "temperature sensitivity of litter respiration". These terms were used in searches of the Web of Science and the China Knowledge Resource Integrated Database (CNKI). Studies lacking replication in their experimental design (e.g., Kim et al., 2005; Ngao et al., 2005; Cisneros-Dozal et al., 2007; Liang et al., 2010; Berryman et al., 2013) were excluded. Papers with artificial litter inputs (e.g., Fang et al., 2015) were also excluded. If an article only reported the standard error, the standard deviation was calculated through the following equation:

$S D=S E \sqrt{ } N(1)$

Where, $\mathrm{N}=$ number of replicates.

To conduct a comprehensive analysis, the final dataset comprised 66 studies (Table S1) conducted between 1989-2020, including 2436 observations of which 1543 observations were from broad-leaved forest, 408 observations were from coniferous forest, and 485 observations were from mixed forest.

\subsection{Meta-analysis}

The raw data were either obtained from tables or extracted by digitizing graphs using the GetData Graph Digitizer (version 2.24, Russian Federation). For each paper, the following information was compiled: source(s) of data, location (e.g., longitude, latitude, and altitude), climatic information (e.g., mean annual temperature and precipitation), vegetation type (e.g., coniferous forest, broad-leaved forest, and mixed forest), stand age [e.g., young forest ( [?] 30 years), middle-aged forest (30-100 years), and mature forest ( [?] 100 years)], soil microbial quantity (e.g., total, fungal, and bacterial PLFA ) and community structure (e.g., fungal/bacterial PLFA ratio), soil microbial biomass carbon (MBC), soil dissolved organic carbon (DOC), soil temperature and moisture, and soil respiration.

The effect size for each investigation was calculated as the natural log-transformed response ratio (lnRR):

$\ln R R=\frac{\ln X_{t}}{\ln X_{c}}=\ln X_{t}-\ln X_{c}(2)$ 
Where $\mathrm{RR}$ is the response ratio, $X_{t}$ is the mean soil respiration in the plots receiving litter, $X_{c}$ is the mean soil respiration without litter. The weighted mean effect size $\left(\mathrm{RR}_{++}\right)$for each categorical subdivision was calculated, and a bias-corrected 95\% confidence interval (CI) was determined by applying a bootstrapping procedure using MetaWin 2.1 (Sinauer Associates, Sunderland, USA) (Hedges et al., 1999; Luo et al., 2006). The detailed calculation of the weight $(\mathrm{w})$ and variance $(\mathrm{v})$ of each $\mathrm{RR}$ as well as the weighted mean effect size $\left(\mathrm{RR}_{++}\right)$were described as detailed in Zhou et al., (2014) and Zhou et al., (2016). The effect of litter inputs on soil respiration within a categorical subdivision was considered significant at $P<0.05$ if the $95 \%$ CIs did not include 0. In addition, the increase in soil respiration (\%) was calculated using the following formula (Chang et al., 2014):

$\left(e^{\mathrm{RR}_{++}}-1\right) \times 100 \%(3)$

Statistical analyses (relationships among the increase in soil respiration and the increase in labile C availability and soil microorganisms) were performed using SigmaPlot 10.0 software (Systat Software, Inc., San Jose, CA, USA).

\section{Results}

\subsection{Effect of litter inputs on soil respiration}

Soil respiration was increased significantly by litter inputs (Fig. $1, P<0.05$ ). Overall, soil respiration increased by $35.7 \%$ and $55.0 \%$ in response to normal and doubled litter inputs, respectively (Fig. 1). Respiration from the coniferous forest soil was increased by $42.2 \%$ and $99.1 \%$ in response to normal and doubled litter inputs, respectively, whilst respiration from the broad-leaved forest soil was increased by $36.9 \%$ and $49.9 \%$ in response to normal and doubled litter inputs, respectively (Fig. 1). For the mixed forest soil respiration was increased by $22.2 \%$ and $51.0 \%$ in response to normal and doubled litter inputs, respectively (Fig. 1).

\subsection{Effect of labile $\mathrm{C}$ availability on soil respiration in response to litter inputs}

Labile $\mathrm{C}$ availability (e.g., DOC and MBC) was increased significantly by litter inputs (Fig. $2, P<0.05$ ). Overall, MBC was increased by $21.0 \%$ and $60.3 \%$ in response to normal and doubled litter inputs, respectively (Fig. 2a). For the coniferous forest, broad-leaved forest, and mixed forest MBC was increased by $12.9 \%$ to $366.0 \%$ in response to normal and doubled litter inputs, respectively (Fig. 2a). Overall, DOC was increased by $33.6 \%$ and $87.7 \%$ in response to normal and doubled litter inputs, respectively (Fig. 2b). For the coniferous forest, broad-leaved forest, and mixed forest DOC was increased by $10.3 \%$ to $146.0 \%$ in response to normal and doubled litter inputs, respectively (Fig. 2b). In response to litter inputs, soil respiraiton increased linearly with corresponding increases in DOC and MBC (Fig. 3a, b).

\subsection{Effect of soil microorganisms on soil respiration in response to litter inputs}

Soil microorganisms (e.g., microbial quantity and community structure) were influenced significantly by litter inputs (Fig. 4,P<0.05). Overall, the total PLFA increased by $6.6 \%$ and $19.7 \%$ in response to normal and doubled litter inputs, respectively (Fig. 4a). Total PLFA from the coniferous forest and broad-leaved forest, were increased by $9.8 \%$ to $28.9 \%$ in response to normal and doubled litter inputs, whilst Total PLFA from the mixed forest was decreased by $5.83 \%$ in response to normal litter inputs and increased by $13.2 \%$ in response to doubled litter inputs respectively (Fig. 4a). Overall, fungal PLFA decreased by $35.6 \%$ in response to normal litter inputs, and increased by $10.8 \%$ in response to doubled litter inputs, respectively (Fig. 4b). Fungal PLFA from the coniferous forest were decreased by $51.6 \%$ and $19.0 \%$ in response to normal and doubled litter inputs, respectively (Fig. 4b). Fungal PLFA from the broad-leaved forest was increased by $54.3 \%$ in response to doubled litter inputs (Fig. 4b). For the mixed forest fungal PLFA was decreased by $31.5 \%$ in response to normal litter inputs, but increased by $27.0 \%$ in response to doubled litter inputs (Fig. $4 \mathrm{~b})$. Overall, bacterial PLFA decreased by $10.8 \%$ in response to normal litter inputs, and increased by $29.8 \%$ in response to doubled litter inputs (Fig. 4c). For the coniferous forest bacterial PLFA decreased by $26.3 \%$ in response to normal litter inputs (Fig. 4c), whilst for the broad-leaved forest they were increased by $17.9 \%$ and $67.7 \%$ in response to normal litter and doubled litter inputs, respectively (Fig. 4c), and in the mixed forest 
they were increased by $33.8 \%$ in response to doubled litter inputs (Fig. 4c). Overall, the fungal/bacterial PLFA ratio decreased by $26.9 \%$ and $18.7 \%$ in response to normal and doubled litter inputs, respectively (Fig. 4d). Fungal/bacterial PLFA ratio from the coniferous forest, broad-leaved forest, and mixed forest were decreased by $5.7 \%$ to $31.5 \%$ in response to normal and doubled litter inputs, respectively (Fig. 4d). Similar to the data for labile carbon, soil respiration increased linearly with corresponding increases in total PLFA and decreased linearly with corresponding decreases in fungal/bacterial PLFA ratio, and also closely related with the increase in both bacterial and fungal PLFA (Fig. 5a, b, c, d), respectively.

\subsection{Effect litter inputs on soil microclimate and soil respiration}

Soil microclimate (e.g., soil temperature and soil moisture) was influenced significantly by litter inputs (Fig. $6, P<0.05)$. Soil temperature was decreased by $0.6 \%$ and $0.3 \%$ in response to normal and doubled litter inputs, respectively (Fig. 6). Soil moisture was not influenced by doubled litter inputs but increased by $3.7 \%$ with normal litter inputs (Fig. 6). Soil respiration was, however, unrelated to the changes in soil temperature and soil moisture (Fig. 7a, b, $\mathrm{P}>0.05$ ).

\subsection{Effect of forest type and stand age on soil respiration in response to litter inputs}

The increase in soil respiration induced by litter inputs was significantly influenced by forest type and stand age (Fig. 8a, b, $P<0.05$ ). In response to litter inputs, soil respiration increased by $50.7 \%$ in coniferous forests, $41.3 \%$ in broad-leaved forests, and $31.9 \%$ in mixed forests (Fig. 8a). Analogously, total PLFA increased by $13.8 \%$ and $15.6 \%$ in coniferous and broad-leaved forests, whereas it only increased (statistically insignificant) by $3.1 \%$ in mixed forests (Fig. 9a). Simultaneously, values for DOC were increased by $20.5 \%$ and $91.8 \%$ in coniferous and broad-leaved forests, whereas it only increased $17.7 \%$ in mixed forests (Fig. 9b). Therefore, the effect of forest type on soil respiration seemed to be related to the increase in DOC and total PLFA by litter inputs.

In terms of stand age the largest response of soil respiration to litter inputs occurred in middle-aged (53.3\%) and mature (50.2\%) forests, (Fig. 8b). However, total PLFA decreased by $11.7 \%$ in middle-aged forests and only increased (statistically insignificant) by $3.1 \%$ in mature forests, whereas it increased $57.1 \%$ in young forests (Fig.9 c). For MBC this increased by $21.9 \%$ and $31.4 \%$ in middle-aged and mature forests, whereas it only increased by $10.3 \%$ in young forests (Fig. 9 d). Therefore, the effect of stand age on soil respiration seemed to be only related to the increase in MBC in response to litter inputs.

\section{Discussion}

\subsection{Effect of litter input on labile $\mathrm{C}$ availability and soil respiration}

Our results showed that soil respiration was increased, on average, by $35.7 \%$ in response to normal litter inputs, whilst a doubling of litter inputs increased soil respiration by $55.0 \%$, consistent with previous field studies (Sulzman et al., 2005; Sayer et al., 2007; Zhang et al., 2016; Brechet et al., 2018). Clearly this could be due to the increase in labile C availability through litter input (increased DOC and MBC). Litter inputs could substantially increase labile $\mathrm{C}$ availability for soil microorganisms in the mineral soil layer thereby stimulating soil respiration if this is limited by substrate availability (Klotzbucher et al., 2012; Kuzyakov and Blagodatskaya, 2015). Similar to other studies (Leff et al., 2012;Wang et al., 2013; Leitner et al., 2016; Liu et al., 2017), our study showed that DOC and MBC were increased by $33.6 \%-87.7 \%$ and $21.0 \%-60.3 \%$ in response to litter inputs, respectively (Fig. 3c). An increase in respiration due to litter-related enhanced substrate availability is also supported by the positive correlation between soil respiration and an increase in DOC and MBC (Fig. 4). Therefore, changes in labile C availability (e.g., DOC and MBC) in response to litter inputs may explain some differences in soil respiration induced by litter inputs.

\subsection{Effect of soil microorganisms on soil respiration in response to litter inputs}

Litter inputs may have also elicited changes in soil respiration indirectly by affecting both the total numbers and population structure of soil microorganisms (Leff et al., 2012). Our results showed that the total PLFA was significantly increased, whilst the fungal/bacterial PLFA ratio was significantly decreased at both high 
and low litter inputs (Fig. 5). This suggest that increased Labile $\mathrm{C}$ availability, or other biological or physical factors associated with litter inputs favored the growth of some microbial groups over others, resulting in shifts in the microbial community, consistent with previous studies (Nadelhoffer et al., 2004; Brant et al., 2006; Strickland et al., 2009; Wang et al., 2013; Wu et al., 2017; Yan et al., 2018). However, increasing litter inputs can have different effects on the soil microbial community composition and quantity, depending on the forest type and season. For example, in a temperate beech forest of Austria, in response to normal litter inputs, the total PLFA increased by $29 \%$ in August, decreased by $12 \%$ in October, and remained largely unchanged in December (Leitner et al., 2016). Another study conducted in three successional subtropical forests in Southern China showed that litter exclusion significantly increased the fungal PLFA and the fungal/bacterial PLFA ratio in a coniferous forest. Whilst litter addition significantly increased the total PLFA in a coniferous and a mixed forest, in a broadleaf forest the soil microbial community was not altered by either litter exclusion or litter addition (Han et al., 2015).

We found that the increase in soil respiration was closely correlated with the increase in total PLFA, bacterial PLFA and fungal PLFA (Fig. 5a, b, c), suggesting that changes in soil microbial biomass in response to litter inputs may explain some variations in soil respiration, similar to earlier studies (Li et al., 2004; Feng et al., 2009; Wang et al., 2013; Han et al., 2015; Leitner et al., 2016; Wu et al., 2017). Analogously, in a coniferous forest ecosystem in central China, basal soil respiration was positively correlated with total PLFA in response to litter inputs (Wu et al., 2017). Fungi and bacteria differ in their strategies for using C, with fungi characterized by a low respiration quotient and a higher efficiency in their use of $\mathrm{C}$ as they produce more biomass C per unit of C metabolized than do bacteria (Strickland and Rousk, 2010; Deng et al., 2016). In response to litter inputs, we found that the increase in soil respiration was closely correlated with the decrease of fungal/bacterial PLFA ratio (Fig. 5d), suggesting that alterations in the relative abundance of fungi and bacteria in response to litter inputs may explain some variations in soil respiration, similar to earlier studies (Wang et al., 2013; Han et al., 2015; Wu et al., 2017). Similarly, in a coniferous forest ecosystem of central China, basal soil respiration was negatively correlated with fungal/bacterial PLFA ratio in response to litter inputs (Wu et al., 2017). Therefore, in addition to labile C availability (e.g., DOC and $\mathrm{MBC}$ ), differences in soil microbial communities in response to litter inputs may also explain some of the changes in soil respiration induced by litter inputs.

\subsection{Effect of soil microclimate on soil respiration in response to litter inputs}

Litter inputs also indirectly influence soil microclimate (e.g., soil temperature and soil moisture) through its effect on soil temperature and the infiltration and evaporation of water (Sulzman et al., 2005; Fekete et al., 2014; Zhang et al., 2014; Han et al., 2015). Soil temperature was decreased by $0.3 \%-0.6 \%$ in response to litter inputs, and soil moisture was increased by $3.7 \%$ in response to normal litter inputs (Fig. 7). However, the effect of litter inputs on soil microclimate can vary with vegetation type (Zhao et al., 2014; Han et al., 2015) and climate (Sayer and Tanner, 2010; Wu et al., 2017; Zhang Yanjun, 2017). Though the soil microclimate (e.g., soil temperature and soil moisture) was influenced slightly by litter inputs (Fig. 7), no significant relationships were found between the increase in soil respiration and soil temperature or soil moisture (Fig. 8,P>0.05). Therefore, changes in soil microclimate in response to litter inputs may not explain the differences in soil respiration, thus contributing little to the difference in soil respiration induced by litter inputs.

\subsection{Effect of forest type and stand age on soil respiration in response to litter inputs}

Similar to other studies (Deng et al., 2007; Yan et al., 2013; Han al., 2015), forest type had a significantly impact on soil respiration in response to litter inputs. Litter- associated increases in soil respiration in coniferous and broad-leaved forests was $58.9 \%$ and $29.5 \%$ higher than that from mixed forests (Fig. 8a), which could be attributed to the change in both total PLFA and labile $\mathrm{C}$ availability. This is likely due to differences in litter quality because in response to litter inputs, different forest type, such as coniferous, broad-leaved, and mixed forests type, produces variable amount of litter contained different concentrations of carbon, nitrogen and other nutrient elements (Deng et al., 2007; Yan et al., 2013). Generally, coniferous forest litter has higher $\mathrm{C} / \mathrm{N}$ ratio and lignin content than broad-leaved forest and mixed forest (Han et al., 
2015), which make different contributions to soil respiration and affects the abundance, composition, and activity of soil microbial communities (Sulzman et al., 2005; Han et al., 2015). In our studies, the total PLFA increased by $13.8 \%$ and $15.6 \%$ in coniferous and broad-leaved forests, respectively, whereas it only increased by $3.1 \%$ in mixed forests (Fig. 9a), and DOC increased by $20.5 \%$ and $91.8 \%$ in coniferous and broad-leaved forests, whereas it only increased by $17.7 \%$ in mixed forests (Fig. 9b).

Previous studies have shown that soil respiration may increase (Yan et al., 2006; Han et al., 2015), decrease (Wang et al., 2016), or remain unchanged (Xiao et al., 2014; Yu et al., 2016; Zhao et al., 2016) with stand age. The effect of stand age on soil respiration may be attributed to the change in soil microclimate (e.g., soil temperature and soil moisture) (Han et al., 2015; Yu et al., 2016), substrate availability (e.g., SOC and MBC) (Xiao et al., 2014; Yu et al., 2016), or litter quantity and quality (Yan et al., 2006; Han et al., 2015; Zhao et al., 2016). In our studies, the effects of litter inputs on soil respiration increased with stand age and was greater (45-55\%) in middle-aged and mature forests compared to young forests and was related to increased labile carbon availability (Fig. 9d). This is because in response to litter inputs, middle-aged and mature forests produced more labile carbon availability than young forests, with MBC in middle-aged and mature forests was 2.1-3.0 times larger than that in young forests (Fig. 9 d). Similarly, in different-aged (e.g., 20-, 30-, and 46-year-old) Pinus massoniana forests in the three gorges reservoir area, litter respiration contribution rate was $31.0 \%-45.9 \%$ for the three different-aged forests, with the lower litter respiration contribution rate occurred in the 30-year-old stands, which can be attributed to the lower soil organic matter and nitrogen contents compared to that in the other two stands (Xiao et al., 2014).

\section{Conclusions}

In this paper, the effects of soil microorganisms (PLFA analysis), soil microclimate, labile C availability, forest type, and stand age on soil respiration in response to litter inputs was analyzed through a metaanalysis. In response to litter inputs, the increase in soil respiration was closely related with the changes in soil microorganisms and labile $\mathrm{C}$ availability, and this was also associated with differences in forest type or stand age. This suggests that the major driver of litter-associated increases in soil respiration is the biological release of labile carbon compounds and the associated changes in soil microbial populations. This will, in turn, depend mainly on litter quality and associated decomposition processes that release labile carbon to the soil, whilst any effects of litter inputs through modifications in soil microclimate would be expected to be small.

Author contributions: Zou Junliang and Xue Siwen conceived and de-signed the experiments, Yu Keke and Dang Shuina collected the datas, Ren Yuanyuan and Liang Ting analyzed the data, Zhang Yanjun and Osborne Bruce wrote the paper.

Acknowledgements: This work was supported by the National Natural Science Foundation of China (Grant No. 41801069), Scientific and Technological Plan Projects in Shaanxi Province (Grant No. 2018JQ3023 and 2019JQ-895), Doctoral Research Project of Baoji University of Arts and Sciences (Grant No. ZK2017041), Special Project on Hi-Tech Innovation Capacity (Grant No. KJCX20200302) and the Excellent Youth Scholars Program from Beijing Academy of Agriculture and Forestry Sciences (BAAFS).

\section{References:}

Ben, B.L., Allison, T., 2010. Temperature-associated increases in the global soil respiration record. Nature 464(7288): 579-582.

Berryman, E., Marshall, J.D., Rahn, T., Litvak, M., Butnor, J., 2013. Decreased carbon limitation of litter respiration in a mortality-affected pinon-juniper woodland. Biogeosciences 10: 1625-1634.

Brechet, L.M., Lopez-Sangil, L., George, C., Birkett, A.J., Baxendale, C., Trujillo, B.C., Sayer, E.J., 2018. Distinct responses of soil respiration to experimental litter manipulation in temperate woodland and tropical forest. Ecology \& Evolution 8(7): 3787-3796.

Brant, J.B., Sulzman, E.W., Myrold, D.D., 2006. Microbial community utilization of added carbon substrates 
in response to long-term carbon input manipulation. Soil Biology \& Biochemistry 38(8): 2219-2232.

Chang, L., Meng, L., Jun, C., Bao, L., Changming, F., 2014. Effects of straw carbon input on carbon dynamics in agricultural soils: A meta-analysis. Global Change Biology 20(5): 1366-1381.

Cisneros-Dozal, L.M., Trumbore, S.E., Hanson, P.J., 2007. Effect of moisture on leaf litter decomposition and its contribution to soil respiration in a temperate forest. Journal of Geophysical Research Biogeosciences 112: $1-10$.

Crow, S.E., Lajtha, K., Bowden, R.D., Yano, Y., Brant, J.B., Caldwell, B.A., Sulzman, E.W., 2009. Increased coniferous needle inputs accelerate decomposition of soil carbon in an old-growth forest. Forest Ecology \& Management 258(10): 0-2232.

Deng, Q., Liu, S.Z., Liu, X.J., Meng, Z., Zhang, D.Q., 2007. Contributions of Litter-fall to Soil Respiration and Its Affacting Factors in Southern Subtropical Forests of China. Advances in Earth Science 22(9): 976986.

Deng, Q., Cheng, X., Hui, D., Zhang, Q., Li, M., Zhang, Q., 2016. Soil microbial community and its interaction with soil carbon and nitrogen dynamics following afforestation in central China. Science of the Total Environment 541: 230-237.

Duan, B.X., Man, X.L., Song, H., Liu, J. L., 2018. Soil respiration and its component characteristics under different types of Larix gmelinii forests in the north of Daxing'an Mountains of northeastern China. Journal of Beijing Forestry University 40(2): 40-50.

Fang, X., Zhao, L., Zhou, G., Huang, W., Liu, J., 2015. Increased litter input increases litter decomposition and soil respiration but has minor effects on soil organic carbon in subtropical forests. Plant \& Soil 1-2(392): 139-153.

Fekete, I., Kotroczo, Z., Varga, C., Nagy, P.T., Varbiro, G., Bowden, R.D., Toth, J.A., Lajtha, K., 2014. Alterations in forest detritus inputs influence soil carbon concentration and soil respiration in a CentralEuropean deciduous forest. Soil Biology \& Biochemistry 74: 106-114.

Feng, W., Zou, X., Schaefer, D., 2009. Above- and belowground carbon inputs affect seasonal variations of soil microbial biomass in a subtropical monsoon forest of southwest China. Soil Biology \& Biochemistry 41(5): $978-983$.

Han, T., Huang, W., Liu, J., Zhou, G., Xiao, Y., 2015. Different soil respiration responses to litter manipulation in three subtropical successional forests. Scientific reports 5.

Hedges, L.V., Gurevitch, J., Curtis, P.S., 1999. The Meta-Analysis of Response Ratios in Experimental Ecology. Ecology 80(4): 1150-1156.

IPCC, Climate change 2007: the physical science basis. Contribution of Work-ing Group I to the fourth assessment report of the intergovernmental panel on climate change. Cambridge University Press, Cambridge.

Kim, H., Hirano, T., Koike, T., Urano, S., 2005. Contribution of litter $\mathrm{CO}_{2}$ production to total soil respiration in two different deciduous forests. . Phyton 45(4): 385-388.

Klotzbucher, T., Kaiser, K., Stepper, C., Loon, E., Gerstberger, P., Kalbitz, K., 2012. Long-term litter input manipulation effects on production and properties of dissolved organic matter in the forest floor of a Norway spruce stand. Plant \& Soil 355(1-2): 407-416.

Kuzyakov, Y., Blagodatskaya, E., 2015. Microbial hotspots and hot moments in soil: Concept \& review. Soil Biology and Biochemistry: 184-199.

Leff, J.W., Wieder, W.R., Taylor, P.G., Townsend, A.R., Nemergut, D.R., Grandy, A.S., Cleveland, C.C., 2012. Experimental litterfall manipulation drives large and rapid changes in soil carbon cycling in a wet tropical forest. Global Change Biology 18(9): 2969-2979. 
Leitner, S., Sae-Tun, O., Kranzinger, L., Zechmeister-Boltenstern, S., Zimmermann, M., 2016. Contribution of litter layer to soil greenhouse gas emissions in a temperate beech forest. Plant \& Soil 403(1-2): 455-469.

Li, Y., Xu, M., Sun, O.J., Cui, W., 2004. Effects of root and litter exclusion on soil $\mathrm{CO}_{2}$ efflux and microbial biomass in wet tropical forests. Soil Biology \& Biochemistry 36(12): 2111-2114.

Liang, N., Hirano, T., Zheng, Z.M., Tang, J., Fujinuma, Y., 2010. Soil $\mathrm{CO}_{2}$ efflux of a larch forest in northern Japan. Biogeosciences 7(11): 3447-3457.

Liu, X., Lin, T.C., Yang, Z., Vadeboncoeur, M.A., Lin, C., Xiong, D., Lin, W., Chen, G., Xie, J., Li, Y., 2017. Increased litter in subtropical forests boosts soil respiration in natural forests but not plantations of Castanopsis carlesii. Plant \& Soil 418(1-2): 141-151.

Luo, Y., Hui, D., Zhang, D., 2006. Elevated $\mathrm{CO}_{2}$ stimulates net accumulations of carbon and nitrogen in land ecosystems: a meta-analysis. Ecology 87(1): 53-63.

Lv, G. C., Wang, X.D., 2017. Contribution of Litters to Soil Respiration : A Review. Soils 49(2): 225-231.

Nadelhoffer, K.J., Boone, R.D., Bowden, R.D., Canary, J.D., Kaye, J., Micks, P., Ricca, A., Aitkenhead, J.A., Lajtha, K., McDowell, W.H., 2004. The DIRT experiment: litter and root influences on forest soil organic matter stocks and function. In: Foster, D., Aber, J. (Eds.), Forest Landscape Dynamics in New England: Ecosystem Struc-ture and Function as a Consequence of 5000 Years of Change. Oxford University Press, New York.

Ngao, J., Epron, D., Brechet, C., Granier, A., 2005. Estimating the contribution of leaf litter decomposition to soil $\mathrm{CO}_{2}$ efflux in a beech forest using 13C" epleted litter. Global Change Biology 11(10): 1768-1776.

Pinto, O.B., Vourlitis, G., Carneiro, E.D.S., Dias, M.D.F., Hentz, C., Nogueira, J.D.S., 2018. Interactions between Vegetation, Hydrology, and Litter Inputs on Decomposition and Soil $\mathrm{CO}_{2}$ Efflux of Tropical Forests in the Brazilian Pantanal. Forests 9(5): 281-.

Sayer, E.J., 2006. Using experimental manipulation to assess the roles of leaf litter in the functioning of forest ecosystems. Biological Reviews 81(1): 1-31.

Sayer, E.J., Powers, J.S.,Tanner, E.V.J., 2007. Increased litterfall in tropical forests boosts the transfer of soil $\mathrm{CO}_{2}$ to the atmosphere. Plos One 2(12): e1299.

Sayer, E.J., Tanner, E.V.J., 2010. A new approach to trenching experiments for measuring root-rhizosphere respiration in a lowland tropical forest. Soil Biology \& Biochemistry 42(2): 347-352.

Strickland, M.S., Lauber, C., Fierer, N., Bradford, M.A., 2009. Testing the functional significance of microbial community composition. Ecology 90(2): 441-451.

Strickland, M.S., Rousk, J., 2010. Considering fungal:bacterial dominance in soils - Methods, controls, and ecosystem implications. Soil Biology \& Biochemistry 42(9): 1385-1395.

Sulzman, E.W., Brant, J.B., Bowden, R.D., Lajtha, K., 2005. Contribution of aboveground litter, belowground litter, and rhizosphere respiration to total soil $\mathrm{CO} 2$ efflux in an old growth coniferous forest. Biogeochemistry 73(1): 231-256.

Sun, Y., Wei, J., Wu, G., Zhao, J.Z., 2005. Soil respiration and affecting factors on the alpine tundra of Changbai Mountain. Chinese Journal of Ecology 24(6): 603-606.

Tian, Q., Wang, D., Tang, Y., Li, Y., Liu, F., 2019. Topographic controls on the variability of soil respiration in a humid subtropical forest. Biogeochemistry.

Veres, Z., Kotroczó, Z., Fekete, I., Tóth, J.A., Lajtha, K., Townsend, K., Tóthmérész, B., 2015. Soil extracellular enzyme activities are sensitive indicators of detrital inputs and carbon availability. Applied Soil Ecology 92: 18-23. 
Wang, G.J., Yan, W.D., Tian, D. L., Zhu, F., Xiang, W.H., Liang, X.C., 2009. Effects of Aboveground Litter Exclusion and Addition on Soil Respiration in A Cunninghamia Lanceolata Plantation in China. Chinese Journal of Plant Ecology 33(4): 739-747.

Wang, J., You, Y.M., Huang, X.M., Zhang, J.L., 2016. Characteristics of soil respiration components in the Quercus aliena var. acuteserrata forest chronosequence. Guihaia 36(10): 1205-1213

Wang, Q., He, T., Wang, S., Liu, L., 2013. Carbon input manipulation affects soil respiration and microbial community composition in a subtropical coniferous forest. Agricultural \& Forest Meteorology 178179(Complete): 152-160.

Wu, J., Qian, Z., Fan, Y., Yao, L., Zhang, Q., a Cheng, X., 2017. Does short-term litter input manipulation affect soil respiration and its carbon-isotopic signature in a coniferous forest ecosystem of central China? Applied Soil Ecology 113: 45-53.

Xiao, W.F., Ge, X.G., Zeng, L.X., Huang, Z.L., Lei, J.P., Zhou, B.Z., Li, M.H., 2014. Rates of Litter Decomposition and Soil Respiration in Relation to Soil Temperature and Water in Different-Aged Pinus massoniana Forests in the Three Gorges Reservoir Area, China. Plos One 9(7): e101890.

Xin, Z., Fa-dong, L., Wan-jun, Z., Zhi-pin, A., 2016. Contribution of aboveground litter to soil respiration in Populus davidiana Dode plantations at different stand ages. Journal of Mountain Science 13(6): 1000-1012.

Xu, S., Liu, L.L., Sayer, E.J., 2013. Variability of above-ground litter inputs alters soil physicochemical and biological processes: a meta-analysis of litterfall-manipulation experiments. Biogeosciences 10: 7423-7433.

Yan, J., Lei, W., Yu, H., Tsang, Y.F., Zhang, Y., Wu, J., Fu, X., Ying, S., 2018. Plant litter composition selects different soil microbial structures and in turn drives different litter decomposition pattern and soil carbon sequestration capability. Geoderma 319: 194-203.

Yan, J.H., Wang, Y.P., Zhou, G.Y., Zhang, D.Q., 2006. Estimates of soil respiration and net primary production of three forests at different succession stages in South China. Global Change Biology 12(5): 810-821.

Yan, W.D., Chen, X.Y., Tian, D.L., Peng, Y.Y., Wang, G.J., Zheng, W., 2013. Impacts of changed litter inputs on soil $\mathrm{CO}_{2}$ efflux in three forest types in central south China. Chin Sci Bul(58): 750-757.

Yu, S., Han, H.R., Kang, F.F., Zhao, J.L., Li, T.Y., Gao, J., Song, X.S., 2016. Effects of litter removal on soil respiration Pinus Tabulaeformis natural secondary forests at different ages. Journal of Northwest A\&F University (Nat. Sci. Ed.) 44(7): 122-130.

Zhang, Y. J., Gan, Z.T., Li, R.J., Rui, W., Li, N.N., Zhao, M., Du, L.L., Guo, S.L., Jiang, J.S., Wang, Z.Q., 2016. Litter production rates and soil moisture influences interannual variability in litter respiration in the semi-arid Loess Plateau, China. Journal of Arid Environments 125: 43-51.

Zhang, Y.J., Guo, S.L., Liu, Q.F., Jiang, J.S., 2014. Influence of soil moisture on litter respiration in the semiarid loess plateau. Plos One 9(12): e114558.

Zhang, Y.J., 2017. Variation in the Temperature Sensitivity of Surface Litter Respiration and Its Influencing Factors. Environmental Science 38(8): 3497-3506.

Zhang, Y.J., Dang, S.N., Ren, Y.Y., Liang, T., Yu, K.K., Zou, J.L., 2020. Response of soil respiration to surface litter input based on a meta-analysis. Ecology and Environmental Sciences.

Zhao, X., Zhang, W.J., Shen, H,T., Ai, Z.P., Lian, S.Q., Liu, C.B., 2014. Contributions of aboveground litter to soil respiration in coniferous and deciduous plantations. Chinese Journal of Eco-Agriculture 22(11): $1318-1325$.

Zhao, X., Li, F.D., Zhang, W.J., Ai, Z.P., 2016. Contribution of aboveground litter to soil respiration in Populus davidiana Dodeplantations at different stand ages. Journal of Mountain Science 13(6): 1000-1012. 
Zhou, L., Zhou, X., Shao, J., Nie, Y., He, Y., Jiang, L., Wu, Z., Hosseini Bai, S., 2016. Interactive effects of global change factors on soil respiration and its components: a meta-analysis. Global Change Biology 22(9): 3157-3169.

Zhou, L., Zhou, X., Zhang, B., Lu, M., Luo, Y., Liu, L., Li, B., 2014. Different responses of soil respiration and its components to nitrogen addition among biomes: a meta-analysis. Glob Chang Biol 20(7): 2332-2343.

Zimmermann, M., Meir, P., Bird, M., Malhi, Y., Ccahuana, A., 2009. Litter contribution to diurnal and annual soil respiration in a tropical montane cloud forest. Soil Biology \& Biochemistry 41(6): 1338-1340.

\section{Figure legends}

Fig. 1 Effect of litter input on soil respiration. Numbers in brackets are the corresponding number of observations. Dots with error bars denote the overall mean percentage increase and its 95\% CI. represent significant at $\mathrm{P}<0.05$. CK: normal litter input, DL: doubled litter input. B: Broad-leaved forest, C: Coniferous forest, M: Mixed forest.

Fig. 2 Effect of litter inputs on labile $\mathrm{C}$ availability. Numbers in brackets are the corresponding number of observations. Dots with error bars denote the overall mean percentage increase and its $95 \%$ CI.represent significant at $\mathrm{P}<0.05$. CK: normal litter input, DL: doubled litter input. B: Broad-leaved forest, C: Coniferous forest, M: Mixed forest.

Fig. 3 Relationships between the increase of DOC (a) and MBC (b), and the increase of soil respiration.

Fig. 4 Effect of litter inputs on soil microorganisms. Numbers in brackets are the corresponding number of observations. Dots with error bars denote the overall mean percentage increase and its 95\% CI.represent significant at $\mathrm{P}<0.05$. CK: normal litter input, DL: doubled litter input. B: Broad-leaved forest, C: Coniferous forest, M: Mixed forest.

Fig. 5 Relationships between the increase of total PLFA (a), fungal PLFA (b), bacterial PLFA (c), fungal/bacterial PLFA ratio (d) and the increase of soil respiration.

Fig. 6 Effect of litter inputs on soil microclimate. Numbers in brackets are the corresponding number of observations. Dots with error bars denote the overall mean percentage increase and its $95 \%$ CI.represent significant at $\mathrm{P}<0.05$. CK: normal litter input, DL: doubled litter input.

Fig. 7 Relationships between the increases of soil temperature (a), soil moisture (b) and the increase of soil respiration.

Fig. 8 Effect of forest type and stand age on soil respiration in response to litter inputs. Numbers in brackets are the corresponding number of observations. Dots with error bars denote the overall mean percentage increase and its $95 \%$ CI.represent significant at $\mathrm{P}<0.05$. B: Broad-leaved forest, C: Coniferous forest, M: Mixed forest.

Fig. 9 Effect of forest type total PLFA (a) and DOC (b), and stand age on total PLFA (c) and MBC (d) in response to litter inputs. Numbers in brackets are the corresponding number of observations. Dots with error bars denote the overall mean percentage increase and its 95\% CI.represent significant at $\mathrm{P}<0.05$. B: Broad-leaved forest, C: Coniferous forest, M: Mixed forest.

\section{Hosted file}

image2.emf available at https://authorea.com/users/313203/articles/443777-effects-of-litterinputs-on-soil-respiration-a-meta-analysis

\section{Hosted file}

image3.emf available at https://authorea.com/users/313203/articles/443777-effects-of-litterinputs-on-soil-respiration-a-meta-analysis

\section{Hosted file}


image4.emf available at https://authorea.com/users/313203/articles/443777-effects-of-litterinputs-on-soil-respiration-a-meta-analysis

\section{Hosted file}

image5.emf available at https://authorea.com/users/313203/articles/443777-effects-of-litterinputs-on-soil-respiration-a-meta-analysis

\section{Hosted file}

image6.emf available at https://authorea.com/users/313203/articles/443777-effects-of-litterinputs-on-soil-respiration-a-meta-analysis

\section{Hosted file}

image7.emf available at https://authorea.com/users/313203/articles/443777-effects-of-litterinputs-on-soil-respiration-a-meta-analysis

\section{Hosted file}

image8.emf available at https://authorea.com/users/313203/articles/443777-effects-of-litterinputs-on-soil-respiration-a-meta-analysis

\section{Hosted file}

image9.emf available at https://authorea.com/users/313203/articles/443777-effects-of-litterinputs-on-soil-respiration-a-meta-analysis

\section{Hosted file}

image10. emf available at https://authorea.com/users/313203/articles/443777-effects-of-litterinputs-on-soil-respiration-a-meta-analysis 